\title{
Prokaryote infections in the New Zealand scallops Pecten novaezelandiae and Chlamys delicatula
}

\author{
P. M. Hine*, B. K. Diggles \\ National Institute of Water and Atmospheric Research, PO Box 14-901, Kilbirnie, Wellington, New Zealand
}

\begin{abstract}
Four intracellular prokaryotes are reported from the scallops Pecten novaezelandiae Reeve, 1853 and Chlamys delicatula Hutton, 1873. Elongated $(1025 \times 110 \mathrm{~nm})$, irregular $(390 \times$ $200 \mathrm{~nm}$ ), or toroidal $(410 \times 200 \mathrm{~nm})$ mollicute-like organisms $(\mathrm{M}-\mathrm{LO}$ ) occurred free in the cytoplasm in the digestive diverticular epithelial cells of both scallop species. Those in P. novaezelandiae bore osmiophilic blebs that sometimes connected the organisms together, and some had a rod-like protrusion, both of which resemble the blebs and tip structures of pathogenic mycoplasmas. The M-LOs in C. delicatula had a slightly denser core than periphery. Round M-LOs, $335 \times 170 \mathrm{~nm}$, occurred free in the cytoplasm of agranular haemocytes in $P$. novaezelandiae, without apparent harm to the host cell. In $P$. novaezelandiae, 2 types of highly prevalent (95 to 100\%) basophilic inclusions in the branchial epithelium contained Rickettsia-like organisms (R-LOs). Type 1 inclusions occurred in moderately hypertrophied, intensely basophilic cells, 8 to $10 \mu \mathrm{m}$ in diameter, containing elongate intracellular R-LOs, $2000 \times 500 \mathrm{~nm}$. Type 2 inclusions were elongated and moderately basophilic in markedly hypertrophic branchial epithelial cells, $50 \times 20 \mu \mathrm{m}$ in diameter, containing intracellular organisms $500 \times 200 \mathrm{~nm}$ in diameter. The possible roles of these organisms in pathogenesis is discussed.
\end{abstract}

KEY WORDS: Scallops - Pecten - Chlamys - Digestive epithelium - Branchial epithelium · Haemocytes · Rickettsias · Mollicutes · Mycoplasmas · Tip structure · Ultrastructure

\section{INTRODUCTION}

Since the first reports of Rickettsia-like (RL-O), chlamydia-like (CL-O) and mollicute-like (ML-O) organisms from bivalves (Harshbarger et al. 1977), there have been numerous reports of RL-Os, less of CL-Os, and few reports of M-LOs (Harshbarger et al. 1977, Azevedo 1993). Scallops have been reported with R-LOs (Gulka et al. 1983, Morrison \& Shum 1983, Gulka \& Chang 1984, Leibovitz et al. 1984, Elston 1986, Le Gall et al. 1988), C-LOs (Morrison \& Shum 1982, Leibovitz 1989) and intracellular bacteria (Bower \& Meyer 1991), sometimes associated with lesions (Gulka \& Chang 1984) or mass mortalities (Gulka et al. 1983, Le Gall et al. 1988, Leibovitz 1989).

${ }^{*}$ Present address: National Centre for Disease Investigation, MAF Operations, PO Box 40-742, Upper Hutt, New Zealand. E-mail: hinem@maf.govt.nz
Annual mortality rates among wild New Zealand scallops Pecten novaezelandiae have been estimated at 23 to $39 \%$ (Bull 1976), and while a percentage of mortalities may be due to senescence, disease is suspected to also be the cause of some of these events. Light microscope examination of sections through $P$. novaezelandiae, to determine whether these on-going intermittent mortalities may be due to an infectious agent, has shown considerable sloughing of digestive epithelial cells. A subsequent ultrastructural study revealed the presence of virus-like particles (V-LPs) in sloughing cells (Hine \& Wesney 1997). As similar V-LPs were previously reported to be associated with mortalities among cultured mussels Perna canaliculus (Jones et al. 1996), the V-LPs in scallops may cause excessive sloughing and mortalities. However, subsequent observations on $P$. novaezelandiae showed that many sloughing digestive epithelial cells also contained prokaryotes, in the presence or absence of V-LPs. 
This ultrastructural study was conducted to identify the prokaryotes in the digestive epithelia and to assess their impact on scallop health. During this study, prokaryote infections were also demonstrated in branchial epithelial cells and haemocytes. These infections were also studied, and another commercially important scallop Chlamys delicatula was examined for comparison with Pecten novaezelandiae.

\section{MATERIALS AND METHODS}

Samples of the gill and digestive tract were excised from 220 scallops Pecten novaezelandiae from around the North Island and top of the South Island, collected in 1996 to 1998,388 P. novaezelandiae from the north of the North Island collected in 1999, and 60 queen scallops Chlamys delicatula from the north of the South Island, collected in 1998. Sections through the gills, mantle and digestive organ of $P$. novaezelandiae and the digestive organ of $C$. delicatula were fixed in Davidson's fixative or $10 \%$ formalin in filtered seawater and stained with haematoxylin and eosin.

For transmission electron microscopy (TEM), small $\left(1 \mathrm{~mm}^{3}\right)$ pieces of the gill and digestive gland of Pecten novaezelandiae and the digestive gland of Chlamys delicatula were excised immediately after opening the valves. They were fixed in $2.5 \%$ glutaraldehyde in $0.22 \mu \mathrm{m}$ filtered seawater (FSW) for $1 \mathrm{~h}$, washed twice in FSW, and post-fixed in $1 \% \mathrm{OsO}_{4}$ for $1 \mathrm{~h}$. They were then dehydrated in ascending (50 to $100 \%$ ) ethyl alcohol, embedded in Araldite, thick-sectioned and stained with $1 \%$ toluidine blue in $1 \%$ borax solution. Ultrathin sections were stained with $5 \%$ uranyl acetate for $10 \mathrm{~min}$ and $5 \%$ lead citrate for 5 to $6 \mathrm{~min}$, and examined on a Philips 420ST TEM. Other sections were stained with ruthenium red to compare surface coating of prokaryotes with that of the plasma membrane (Taylor-Robinson et al. 1991).

\section{RESULTS}

The gills and digestive tract of Pecten novaezelandiae were examined by light microscopy, and TEM, and the digestive tract of Chlamys delicatula by light microscopy and TEM, for comparison with P. novaezelandiae.

\section{Pecten novaezelandiae}

Prokaryotes in digestive epithelial cells

Sections through the digestive diverticulae showed the normal highly vacuolated ghost cells and concentric masses of yellowish amorphous matter in the lumen, commonly found in Pecten spp. There was no evidence of basophilic inclusions in the remnant basiphil and absorptive cells lining the diverticulae, or in sloughing absorptive cells. Prevalence of prokaryotes in sloughing digestive epithelial cells could not therefore be determined by light microscopy. Ultrastructural observations on sloughing digestive epithelial cells of 127 of the 220 Pecten novaezelandiae sampled, showed 117 (92\%) of scallops to be infected. As only 1 section through the digestive diverticulae could be examined from each scallop, the 10 apparently negative scallops may also have been infected elsewhere in the digestive diverticulae. Within individual oysters, nearly all the absorptive cells were infected.

Ultrastructurally, attached and sloughed digestive epithelial cells contained intracytoplasmic polymorphic prokaryotes, lacking a cell wall and bounded by a single trilaminar membrane, which were dispersed throughout the cells, in direct contact with the cytosol (Figs. 1 to 3). These prokaryotes were vermiform, $1025 \times 110 \mathrm{~nm}$ (Fig. 2), irregular, $390 \times 200 \mathrm{~nm}$ (Fig. 3) or toroidal, $410 \times 200 \mathrm{~nm}$ (Fig. 4) in shape, sometimes with a clear elongated protrusion (Figs. 5 to 7), and internally had a few peripheral ribosomes and central filaments (Figs. 3 to 6). Elongated forms bore a terminal osmiophilic bleb (Figs. 3 \& 8) that sometimes appeared striated or laminated (Fig. 9), with striations 4 to $6 \mathrm{~nm}$ in periodicity, and these were frequently seen to attach one organism to another (Fig. 10). Identical laminated structures also lay free in the cytoplasm (Fig. 11). Sometimes the prokaryotes lay in intracytoplasmic vacuoles, with the vacuole showing a similar slightly flocculent surface to that of the prokaryote (Fig. 7). Rarely, groups of apparently degenerating bodies with an osmiophilic core, and dense bodies, 230 to $130 \mathrm{~nm}$, bounded by a single trilaminar membrane, were seen among the cellular debris (Fig. 12). Groups of similar bodies had a dense core and clear space between the core and membrane (Fig. 13).

Some sloughing digestive cells were co-infected with V-LPs, which occurred among the prokaryotes. Host-cell Golgi bodies were occasionally seen to be actively producing an osmiophilic substance, and hostcell mitochondria were very dense and surrounded by a double membrane. The cytosol was also composed of membrane-attached V-LPs, ribosomes, membranous debris, glycogen and dense granules bounded by a double membrane.

\section{Prokaryotes in haemocytes}

As this study was specifically carried out on digestive epithelial cells and branchial epithelial cells, haemo- 


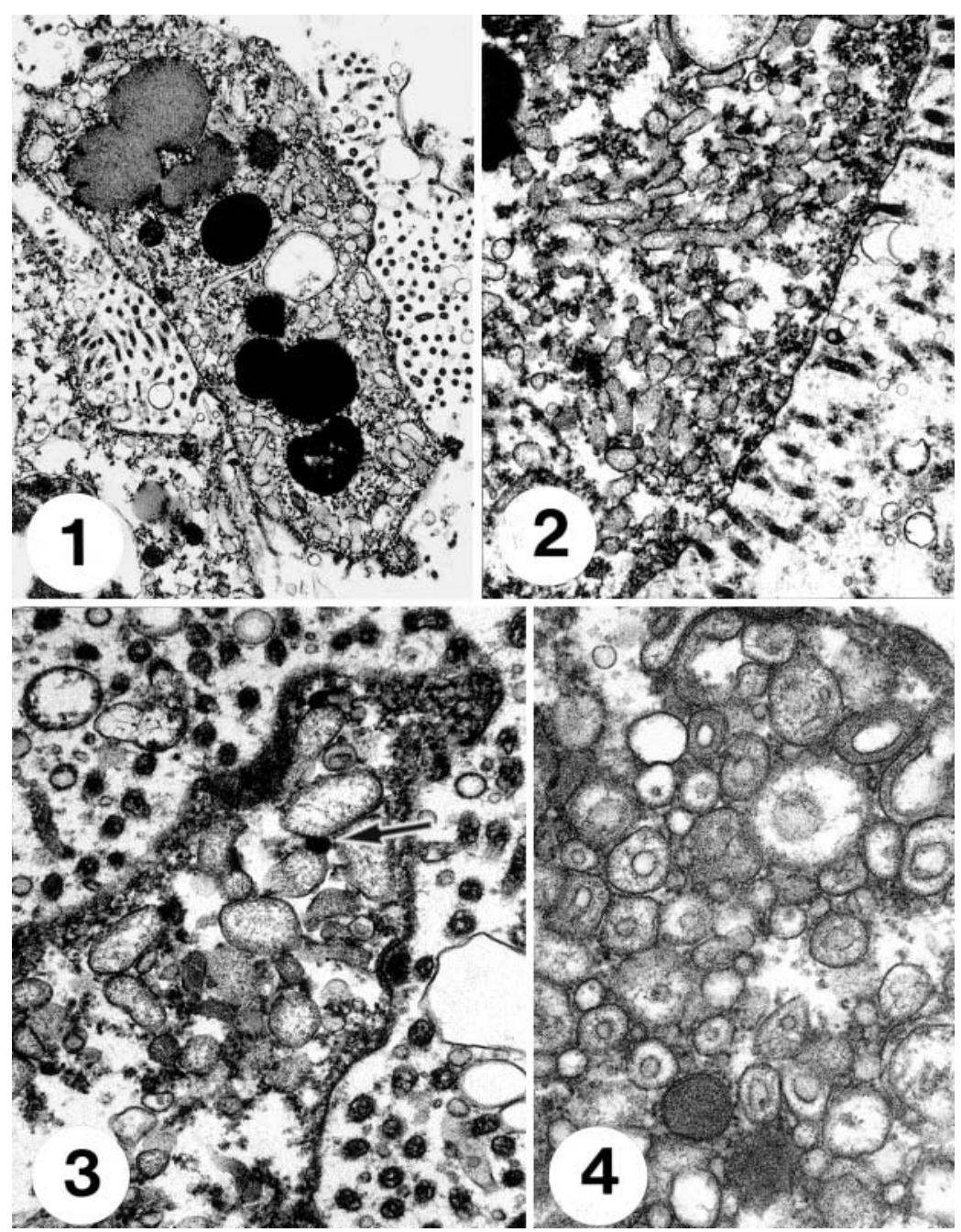

Figs. 1 to 4. Pecten novaezelandiae. Infection of digestive epithelial cells. Fig. 1. Sloughing digestive epithelial cell heavily infected with prokaryotes $(\times 1 \overline{1550)}$. Fig. 2. Cytoplasm of a sloughing cell containing elongated prokaryotes $(\times 19380)$. Fig. 3 . Detail of sloughing cell showing polymorphic prokaryotes; note that 2 are attached by an osmiophilic bleb (arrow) $(\times 41140)$. Fig. 4. Toroidal prokaryotes lying directly in the host cell cytoplasm $(\times \overline{49550)}$

Prokaryotes in branchial epithelial cells

Branchial epithelial cells (Fig. 17) of 80 to $100 \%$ of the scallops examined were infected by 2 types of basophilic inclusions containing prokaryotes. Type 1 inclusions occurred in moderately hypertrophied, intensely basophilic cells, 8 to $10 \mu \mathrm{m}$ in diameter, containing elongate intracellular organisms, $2000 \times 500 \mu \mathrm{m}$ (Fig. 18). Type 2 inclusions were elongated and moderately basophilic in markedly hypertrophic branchial epithelial cells, $50 \times 20 \mu \mathrm{m}$ in diameter (Fig. 19), containing intracellular organisms $500 \times$ $200 \mathrm{~nm}$ in diameter. Type 1 inclusions were common at all sites, but Type 2 inclusions were variable and intermittent in distribution. Ultrastructurally, the prokaryotes occurred in an inclusion and were rod-shaped, with a periphery of dense ribosomes and a less dense central region containing putative filaments of nucleic acid (Fig. 20). Each organism was surrounded by a wavy membrane (Fig. 20). Large elongated basophilic inclusions also occurred in the epithelium of the mantle in 23 to $100 \%$ of scallops from each area (data not shown).

\section{Chlamys delicatula}

Of the 60 Chlamys delicatula studied, 20 were examined ultrastructurally, and all of these 20 had prokaryotes in the digestive epithelial cells. Histologically, the digestive diverticulae appeared as in Pecten novaezelan-

cytes were rarely observed. However, haemocytes were observed in 16 of the 127 Pecten novaezelandiae studied by TEM, and prokaryotes were observed in the haemocytes of 14 of the 16 scallops. Intracytoplasmic spherical prokaryotes, $335 \times 170 \mathrm{~nm}$, lacking a cell wall and bounded by a single trilaminar membrane, also occurred in agranular haemocytes (Fig. 14), in direct contact with the cytosol (Fig. 15). They contained ribosomes, but nucleic acid filaments were not apparent. Constriction of some individuals, and attachment of twin organisms suggested that they divided by binary fission (Fig. 16). Although these prokaryotes occupied much of the cytoplasm, the nuclei of the haemocytes appeared to be normal, suggesting they were unaffected by their presence. diae. Ultrastructurally, some attached and many sloughed digestive epithelial cells contained intracytoplasmic polymorphic prokaryotes, $205 \times 115 \mathrm{~nm}$, lacking a cell wall and bounded by a single trilaminar membrane. They were dispersed throughout the cells, in direct contact with the cytosol (Fig. 21). They were circular or irregular in shape and contained many ribosomes but lacked nucleic acid filaments (Figs. 21 \& 22), or were circular with peripheral ribosomes and a central filamentous nucleoid (Fig. 23). The circular to irregular forms with many ribosomes appeared to develop central dense nucleoids as they elongated and divided by binary fission to form circular forms with a nucleoid (Fig. 24). Host cells lacked organelles such as mitochondria and Golgi 


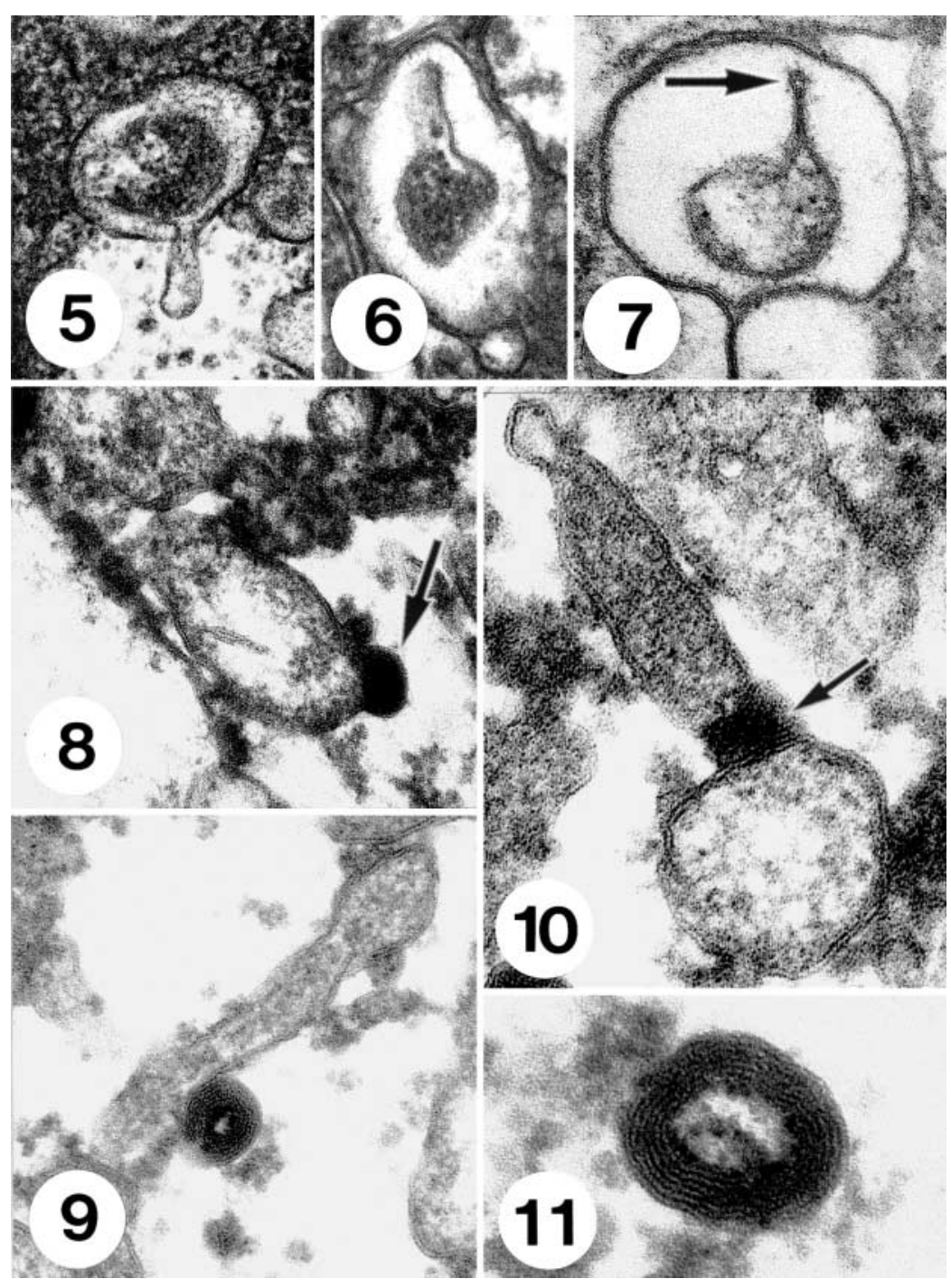

Figs. 5 to 11. Pecten novaezelandiae. Morphology of prokaryotes in digestive epithelial cells. Fig. 5. Toroidal prokaryote showing protrusion into a space containing glycogen granules $(\times 70650)$. Fig. 6. Prokaryote packed with ribosomes showing rod-like protrusion $(\times 11720 \overline{0)}$. Fig. 7 . Prokaryote lying in a vacuole, showing protrusion of a tip-structure (arrow) and a slightly flocculent surface similar to that lining the vacuole; ruthenium red $(\times 135050)$. Fig. 8. Intracytoplasmic prokaryote bearing an osmiophilic bleb (arrow) $(\times 116200)$. Fig. 9. Striated or laminated structure lying on a prokaryote $(\times 135000)$. Fig. 10. Two prokaryotes joined by a striated bleb (arrow) $(\times 193700)$. Fig. $\overline{11 . ~ S t r i a t e d ~}$ structure lying free in the cytosol $(\times 240300)$

bodies, and the cytosol mainly comprised ribosomes and membranous debris.

\section{DISCUSSION}

With the exception of a recent study identifying an intracellular prokaryote causing withering syndrome in abalone as a member of the Rickettsiales (Friedman et al. 2000), identification of intracellular prokaryotes of molluscs has relied on ultrastructural studies. While such studies do not permit specific or generic identification, they can be used to identify the group to which the prokaryotes belong. However, it is difficult to determine the prevalence and intensity of infection, because infection may be localized and not encountered in the few ultra-thin sections examined, and intensity may differ in different parts of an infected organ. The branchial basophilic prokaryotic inclusions in Pecten novaezelandiae resemble R-LOs reported from $P$. maximus both in the 2 types of inclusions and in the ultrastructure of the R-LOs within the inclusions (Le Gall et al. 1988).

The other prokaryotes encountered are less easy to identify. The organisms in epithelial cells of the digestive diverticulae of Pecten novaezelandiae and Chlamys delicatula, and in the haemocytes of $P$. novaezelandiae possessed a trilaminar plasma membrane but lacked cell walls, thus resembling mollicutes. However, the presence or absence of cell walls must be treated with caution as both rickettsial and chlamydial prokaryotes may produce cell wall defective variants (Kordová 1978, Hase 1985). Normal R-LOs and C-LOs have walls similar to Gramnegative bacteria, although rickettsial walls may vary between species even in the same genus (Silverman 1991), and chlamydial walls lack a peptidoglycan layer (Moulder 1991). The absence of an inclusion membrane is taxonomically important, as R-LOs (Leibovitz et al. 1984, Elston 1986, Le Gall et al. 1988 ) and C-LOs (Morrison \& Shum 1982, Leibovitz 1989, Johnson \& Le Pennec 1995) occur in intracellular inclusions, visible as basophilic inclusions under the light microscope. The chlamydial inclusion membrane is particularly important as it mediates contact with host cell organelles (Moulder 1991, Hackstadt et al. 1997, Hackstadt 2000). Mollicutes occur either in deep invaginations of the plasma membrane or free in the cytoplasm (Taylor-Robinson et al. 1991, Baseman et al. 1995, Razin et al. 1998), and are not visualized by light microscopy. Based on the lack of cell wall and the absence of an inclusion, the 


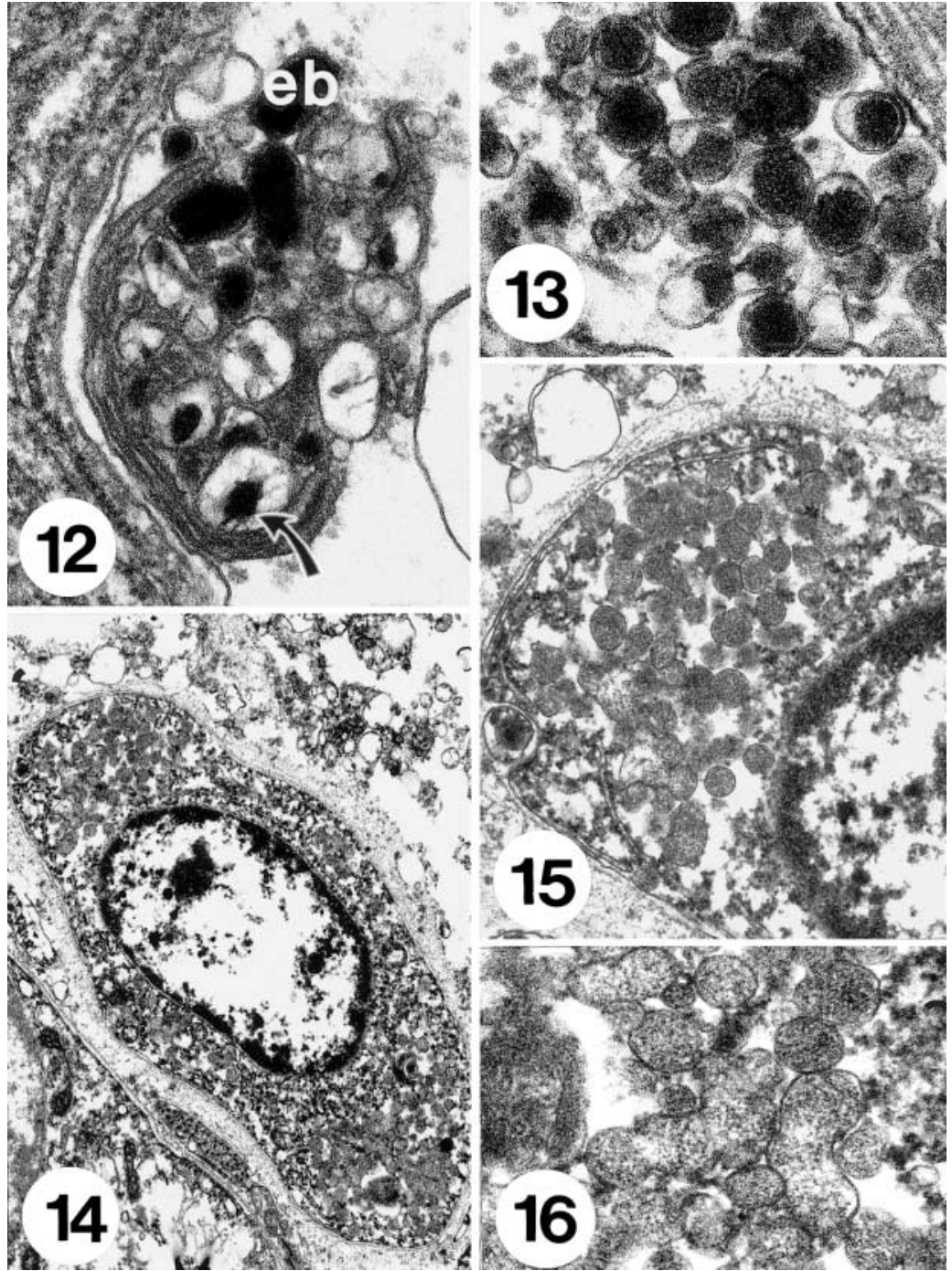

Figs. 12 \& 13. Pecten novaezelandiae. Possible stages of a prokaryote in digestive cells. Fig. 12. group of possible prokaryotes showing a possible nucleoid (arrow) and elementary bodies (eb) ( $\times 69230)$; Fig. 13. group of bodies resembling elementary bodies of a prokaryote $(\times 96260)$. Figs. 14 to 16 . Prokaryotes in haemocytes. Fig. 14. Agranular haemocyte containing intracytoplasmic prokaryotes $(\times 12 \overline{210}) ;$ Fig. 15. greater detail of the haemocyte in Fig. 14 showing prokaryotes free in the cytosol $(\times 30010)$; Fig. 16. wall-less prokaryotes in the haemocyte cytoplasm $(\times 54830)$

digestive cell and haemocyte organisms are considered mollicutes.

Two notable features of the prokaryotes in the digestive cells of Pecten novaezelandiae were the common occurrence of osmiophilic bleb-like protrusions (Figs. 3 \& 8), and an elongated rod-like structure (Figs. 5 to 7). Mollicutes lack features, but some pathogenic mycoplasmas show polarity and have apical bleb-like protrusions (Archer 1981) or nap (Tully et al. 1983), which may be utilized in attachment to host cells or to each other (Jensen et al. 1994), and which may be striated (Tully et al. 1983; see present Figs. 9 to 11). They contain enzymes and resemble the nap-like protrusions observed here. Vesicular inclusions in the periphery of mollicutes infecting red claw crayfish Cherax quadricarinatus have also been identified as blebs (Jiménez et al. 1998), but they were not osmiophilic and did not protrude from the surface of the mollicute, as observed in mammalian mycoplasmas and in this study.

Also, the long rod-like extension shown in Figs. 6 \& 7 resembles the tip structure used by pathogenic mycoplasmas to attach to and penetrate host epithelial cells (Lo et al. 1993, Jensen et al. 1994, Abdul-Wahab et al. 1996, Trachtenberg 1998, Romero-Arroyo et al 1999). Tip structures utilize cytadhesins for attachment, but attachment and penetration can also occur in the absence of tip structures (Salih \& Rosenbusch 1988, Jensen et al. 1994). Mycoplasmas of higher animals utilize nap or tip structures when actively invading epithelial cells, but they are unnecessary when mycoplasmas are endocytosed by host cells (Razin et al. 1998). The presence of apical nap and apparent tip structures in the mollicutes infecting the digestive epithelial cells of $P$. novaezelandiae suggests that the cells may be actively invaded by the mollicute. However, mollicutes bearing nap were only observed in direct contact with the cytoplasm (Figs. 3 \& 5), and those with tip structures in vacuoles (Figs. $6 \&$ 7). The function of these structures in relation to cytadhesion and penetration needs to be clarified before their identity can be verified.

The dense bodies rarely observed in the necrotic debris of degenerating Pecten novaezelandiae digestive cells (Figs. 12 \& 13) may or may not be developmental stages of a prokaryote. The dense bodies do resemble the elementary bodies of chlamydias (Morrison \& Shum 1982, Leibovitz 1989, Miyashita et al. 1993), and even rickettsias may form similar bodies (Popov et al. 1995). They may be stages of an underlying chlamydial infection, or simply secretory granules. Further research is needed to determine their identity.

Few serious, or potentially serious, infective organisms have been reported from scallops (Moyer et al. 


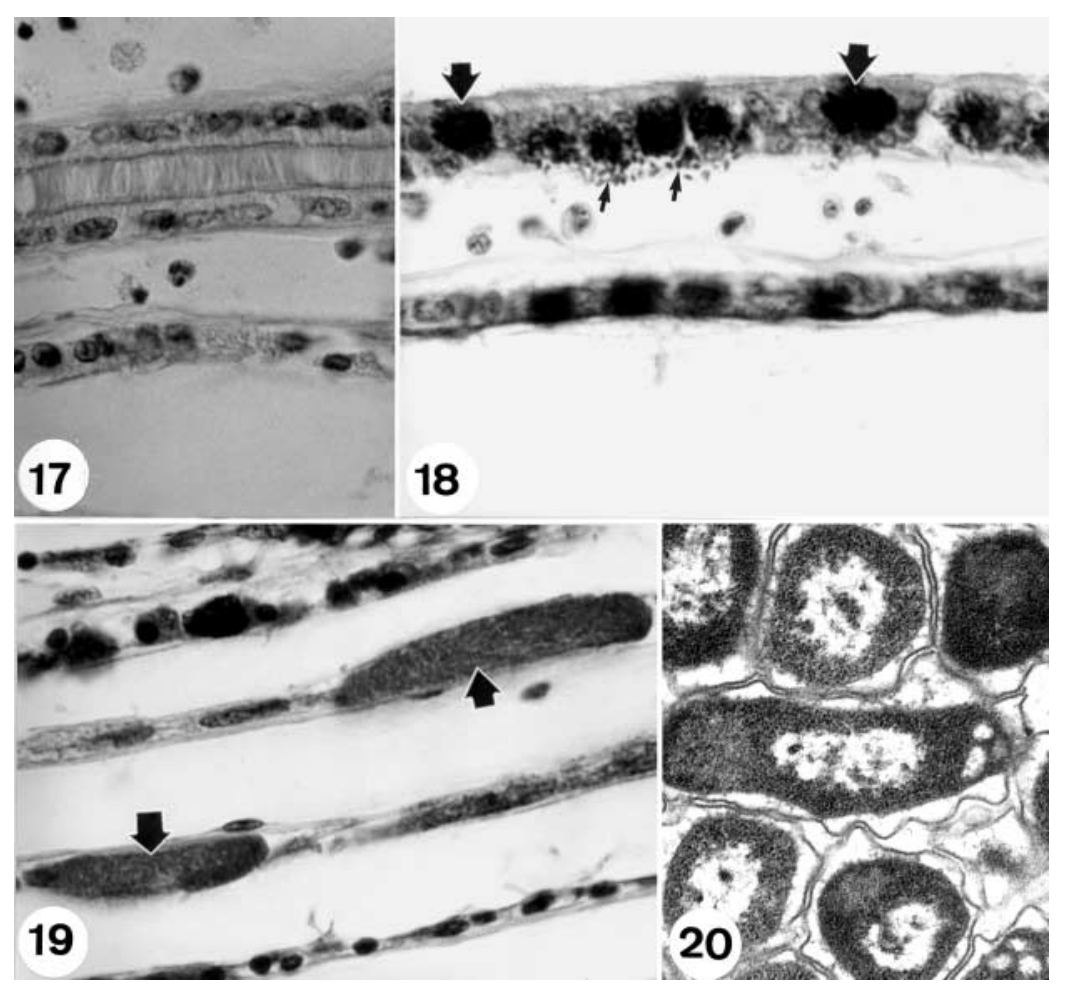

Figs. 17 to 20. Pecten novaezelandiae. R-LOs in branchial epithelial cells. Fig. 17. Normal branchial epithelium $(\times 1375)$. Fig. 18. Branchial epithelium with highly basophilic Type 1 R-LO inclusions (large arrows) and elongate intracellular organisms (small arrows) $(\times 1375)$. Fig. 19. Two elongated, moderately basophilic Type 2 R-LO inclusions (arrows) $(\times 1375)$. Fig. 20. TEM of rod-shaped intracellular R-LOs from the branchial epithelium showing wavy outer membrane, periphery of dense ribosomes and less dense central region $(\times 49000)$

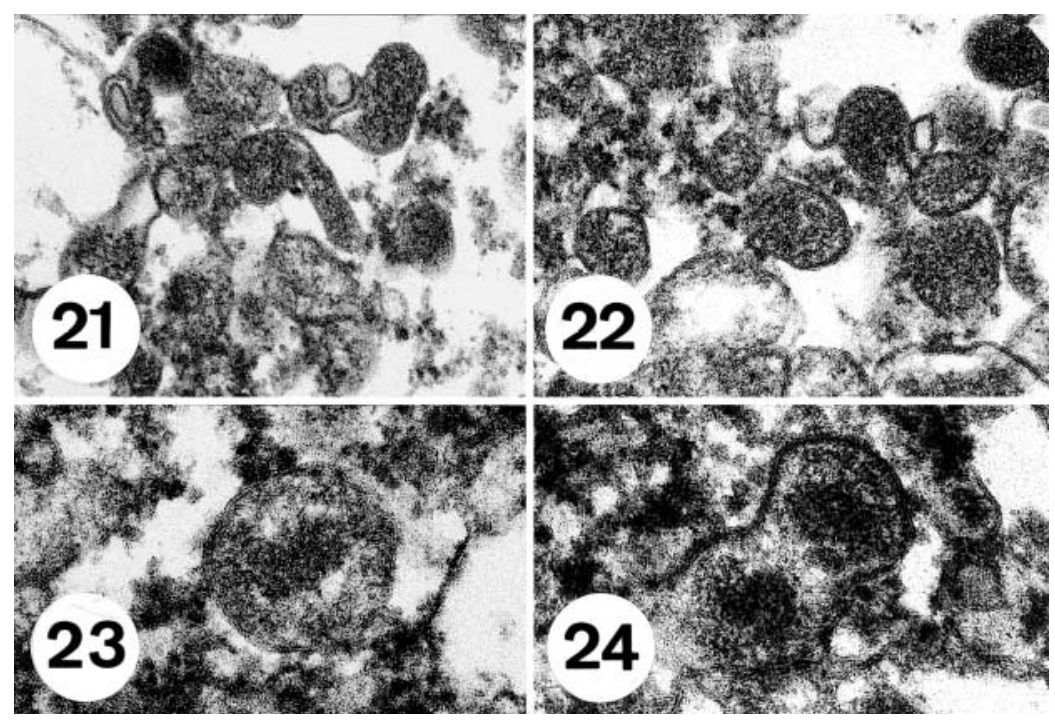

Figs. 21 to 24. Chlamys delicatula. Prokaryotes in digestive epithelial cells. Fig. 21. Polymorphic wall-less prokaryotes free in the cytosol of a digestive epithelial cell $(\times 72860)$. Fig. 22. Rounded prokaryotes free in the cytosol of a digestive epithelial cell, showing the organisms packed with ribosomes (×90630). Fig. 23. Prokaryote showing a dense nucleoid-like centre $(\times 118400)$.

Fig. 24 . Division of forms with a dense nucleoid-like centre $(\times 127920)$
1993, Whyte et al. 1994, Bower et al. 1998), and yet mass mortalities are common in wild and cultured scallop stocks in many countries (Leibovitz et al. 1984). The presence of intracellular prokaryotes in scallops raises the question of their possible role in pathogenesis. Mortality rates of 23 to $39 \%$ reported among Pecten novaezelandiae by Bull (1976) are similar to the 30\% mortalities in rickettsial epizootics in $P$. maxima (Le Gall et al. 1991), and in both cases the R-LOs are highly prevalent (90 to 100\%). Branchial R-LO infections may also occur in Chlamys delicatula, similar to those reported from C. varia and C. operculata in France (Le Gall et al. 1991). Branchial R-LO infections may adversely affect the host directly by release of enzymes such as acid phosphatases and catalase (Le Gall \& Mialhe 1992), or indirectly by destroying the respiratory function of branchial epithelial cells, causing respiratory impairment and, when many cells are infected, death. The mollicutes in haemocytes may be similar to those reported from the haemocytes of Japanese scallops Patinopecten yessoensis, which were associated with failure to thrive, lesions in the adductor muscle, widespread connective tissue lesions, or death, depending on the level of infection (Bower \& Meyer 1991, 1995).

The possible role in pathogenesis of the digestive cell mollicute in Pecten novaezelandiae is more difficult to assess because of the co-occurrence of V-LPs in many sloughing cells. Detached cells contained V-LPs only, mollicutes only, or both, but proportions varied greatly between tubules and between scallops. M-LOs may reduce food absorption by the scallops, and secretion of hydrogen peroxide and superoxide radicals directly into the cytoplasm is probably mildly toxic to host cells (Razin et al. 1998). Nap and rod-like tip structures are characteristics of pathogenic Mycoplasma spp. (Tully et al. 1983, Abdul-Wahab et al. 1996), and may indicate pathogenicity of the mollicute in $P$. novaezelandiae digestive cells. Considered separately, 
the V-LP and prokaryote infections of scallops may not appear harmful to the host, but considered together at moderate to high intensities, and in the apparent absence of other possible pathogens, they may physiologically stress the host, resulting in mass mortalities.

There are 2 possible reasons why scallops are particularly prone to prokaryote infections. Firstly, scallops appear to lack granulocytes which, in other bivalves, phagocytose bacteria (Hine 1999). Secondly, R-LOs (Buchanan 1978, Wen et al. 1993, Comps \& Tigé 1999) and C-LOs (Harshbarger et al. 1977, Johnson \& Le Pennec 1995) of bivalves are often infected with phages, which appear to control populations of these prokaryotes in bivalves. Phages have not been reported from scallop non-eubacterial prokaryotes, and this has possibly permitted them to spread unchecked. Experimental infection studies are needed to determine the pathogenicity of these organisms in scallops.

\section{LITERATURE CITED}

Abdul-Wahab OM, Ross G, Bradbury JM (1996) Pathogenicity and cytadherence of Mycoplasma imitans in chicken and duck embryo tracheal organ cultures. Infect Immun 64:563-568

Archer DB (1981) The structure and functions of the mycoplasma membrane. Int Rev Cytol 69:1-44

Azevedo C (1993) Occurrence of an unusual branchial mycoplasma-like infection in cockle Cerastoderma edule (Mollusca, Bivalvia). Dis Aquat Org 16:55-59

Baseman JB, Lange M, Criscimagna NL, Giron JA, Thomas CA (1995) Interplay between mycoplasmas and host target cells. Microb Pathog 19:105-116

Bower SM, Meyer G (1991) Disease of Japanese scallops (Patinopecten yessoensis) caused by an intracellular bacterium. J Shellfish Res 10:531

Bower SM, Meyer G (1995) Causes of mortalities among cultured Japanese scallops (Patinopecten yessoensis) in British Columbia. J Shellfish Res 14:227

Bower SM, Blackbourn J, Meyer GR (1998) Distribution, prevalence, and pathogenicity of the protozoan Perkinsus qugwadi in Japanese scallops, Patinopecten yessoensis, cultured in British Columbia, Canada. Can J Zool 76: 954-959

Buchanan JS (1978) Cytological studies on a new species of rickettsia found in association with a phage in the digestive gland of the marine bivalve mollusc, Tellina tenuis (da Costa). J Fish Dis 1:27-43

Bull MF (1976) Aspects of the biology of the New Zealand scallop, Pecten novaezelandiae Reeve 1853, in the Marlborough Sounds. PhD thesis, Victoria University of Wellington

Comps M, Tigé G (1999) Procaryotic infections in the mussel Mytilus galloprovincialis and in its parasite the turbellarian Urastoma cyprinae. Dis Aquat Org 38:211-217

Elston R (1986) Occurrence of branchial rickettsiales-like infections in two bivalve molluscs, Tapes japonica and Patinopecten yessoensis, with comments on their significance. J Fish Dis 9:69-71

Friedman CS, Andree KB, Beauchamp KA, Moore JD, Rob- bins TT, Shields JD, Hedrick RP (2000) 'Candidatus xenohaliotis californiensis', a newly described pathogen of abalone, Haliotis spp., along the west coast of North America. Int J Syst Evol Microbiol 50:847-855

Gulka G, Chang PW (1984) Pathogenicity and infectivity of a rickettsia-like organism in the sea scallop, Placopecten magellanicus. J Fish Dis 8:309-318

Gulka G, Chang PW, Marti KA (1983) Prokaryotic infection associated with a mass mortality of the sea scallop, Placopecten magellanicus. J Fish Dis 6:355-364

Hackstadt T (2000) Redirection of host vesicle trafficking pathways by intracellular parasites. Traffic 1:93-99

Hackstadt T, Fischer ER, Scidmore MA, Rockey DD, Heinzen RA (1997) Origins and functions of the chlamydial inclusion. Trends Microbiol 5:288-293

Harshbarger JC, Chang SC, Otto SV (1977) Chlamydiae (with phages), mycoplasmas, and Rickettsiae in Chesapeake Bay bivalves. Science 196:666-668

Hase T (1985) Developmental sequence and surface membrane assembly of Rickettsiae. Annu Rev Microbiol 39: $69-88$

Hine PM (1999) The inter-relationships of bivalve haemocytes. Fish Shellfish Immunol 9:367-385

Hine PM, Wesney B (1997) Virus-like particles associated with cytopathology in the digestive gland epithelium of scallops Pecten novaezelandiae Reeve, 1853 and toheroa Paphies ventricosum (Gray, 1843). Dis Aquat Org 29: 197-204

Jensen JS, Blom J, Lind K (1994) Intracellular location of Mycoplasma genitalium in cultured Vero cells as demonstrated by electron microscopy. Int J Exp Pathol 75:91-98

Jiménez R, Barniol R, Romero X, Machuca M (1998) A prokaryotic intracellular organism in the cuticular epithelium of cultured crayfish, Cherax quadricarinatus (von Martens), in Ecuador. J Fish Dis 21:387-390

Johnson MA, Le Pennec M (1995) Association between the mollusc bivalve Loripes lucinalis and a Chlamydia-like organism, with comments on its pathogenic impact, life cycle and possible mode of transmission. Mar Biol 123: $523-530$

Jones JB, Scotti PD, Dearing SC, Wesney B (1996) Virus-like particles associated with marine mussel mortalities in New Zealand. Dis Aquat Org 25:143-149

Kordová N (1978) Chlamydiae, rickettsiae, and their cell wall defective variants. Can J Microbiol 24:339-352

Le Gall G, Mialhe E (1992) Purification of rickettsiales-like organisms associated with Pecten maximus (Mollusca: Bivalvia): serological and biochemical characterization. Dis Aquat Org 12:215-220

Le Gall G, Chagot D, Mialhe E, Grizel H (1988) Branchial rickettsiales-like infection associated with a mass mortality of sea scallop Pecten maximus. Dis Aquat Org 4: $229-232$

Le Gall G, Mialhe E, Chagot D, Grizel H (1991) Epizootiological study of rickettsiosis of the Saint-Jacques scallop Pecten maximus. Dis Aquat Org 10:139-145

Leibovitz L (1989) Chlamydiosis: a newly reported serious disease of larval and postmetamorphic bay scallops, Argopecten irradians (Lamarck). J Fish Dis 12:125-136

Leibovitz L, Schott EF, Karney RC (1984) Diseases of wild, captive and cultured scallops. J World Maricult Soc 14: 269-283

Lo SC, Hayes MM, Kotani H, Pierce PF, Wear DJ, Newton PB, Shih JW (1993) Adhesion onto and invasion into mammalian cells by Mycoplasma penetrans: a newly isolated mycoplasma from patients with AIDS. Mod Pathol $6: 276-280$ 
Miyashita N, Kanamoto Y, Matsumoto A (1993) The morphology of Chlamydia pneumoniae. J Med Microbiol 38: $418-425$

Morrison C, Shum G (1982) Chlamydia-like organisms in the digestive diverticula of the bay scallop, Argopecten irradians (Lmk). J Fish Dis 5:173-184

Morrison C, Shum G (1983) Rickettsias in the kidney of the bay scallop, Argopecten irradians (Lamarck). J Fish Dis 6: 537-541

Moulder J W (1991) Interaction of Chlamydiae and host cells in vitro. Microbiol Rev 55:143-190

Moyer MA, Blake NJ, Arnold WS (1993) An ascetosporan disease causing mass mortality in the Atlantic calico scallop Argopecten gibbus (Linnaeus, 1758). J Shellfish Res 12: 305-310

Popov VL, Chen SM, Feng HM, Walker DH (1995) Ultrastructural variation of cultured Ehrlichia chaffeensis. J Med Microbiol 43:411-421

Razin S, Yogev D, Naot Y (1998) Molecular biology and pathogenicity of mycoplasmas. Microbiol Mol Biol Rev 62: $1094-1156$

Romero-Arroyo CE, Jordan J, Peacock SJ, Willby MJ, Farmer MA, Krause DC (1999) Mycoplasma pneumoniae protein P30 is required for cytadherence and asso-

Editorial responsibility: Albert Sparks, Seattle, Washington, USA ciated with proper cell development. J Bacteriol 181: 1079-1087

Salih BA, Rosenbusch RF (1988) Attachment of Mycoplasma bovoculi to bovine conjunctival epithelium and lung fibroblasts. Am J Vet Res 49:1661-1664

Silverman DJ (1991) Some contributions of electron microscopy to the study of Rickettsiae. Eur J Epidemiol $7: 200-206$

Taylor-Robinson D, Davies HA, Sarathchandra P, Furr PM (1991) Intracellular location of mycoplasmas in cultured cells demonstrated by immunocytochemistry and electron microscopy. Int J Exp Pathol 72:705-714

Trachtenberg S (1998) Mollicutes - wall-less bacteria with internal cytoskeletons. J Struct Biol 124:244-256

Tully JG, Taylor-Robinson D, Rose DL, Cole RM, Bove JM (1983) Mycoplasma genitalium, a new species from the human urogenital tract. Int J Syst Bacteriol 33:387-396

Wen CM, Tsen S, Kou GH, Chen SN (1993) Rickettsiaceaelike microorganisms in the cultured hard clam (Meretrix lusoria Röding) in Taiwan. J Fish Soc Taiwan 20:347-356

Whyte SK, Cawthorn RJ, McGladdery SE (1994) Co-infection of bay scallops Argopecten irradians with Perkinsus karlssoni (Apicomplexa, Perkinsea) and an unidentified coccidian parasite. Dis Aquat Org 18:53-62

Submitted: October 19, 2001; Accepted: April 3, 2002

Proofs received from author(s): June 27, 2002 